\title{
A CEFR-based Comparison of English and Turkish Language Teaching Course Books in Terms of Speaking and Writing Skills
}

\section{İngilizce ve Türkçe Öğretimi Ders Kitaplarının Konuşma ve Yazma Becerileri Açısından CEFR'ye Dayalı Karşılaştırması}

\author{
İbrahim Fatih DEMİREL*
}

\author{
Özlem FAKAZLI**
}

Received: 31 December 2020

Research Article

Accepted: 01 March 2021

\begin{abstract}
This study aims to investigate to what extent the competences in the Common European Framework of Reference for Languages (CEFR) are fulfilled in language teaching course books in terms of productive skills (speaking-writing) in foreign/second language teaching. With this purpose in mind, speaking and writing activities in Headway for teaching English as a foreign/second language and in Yeni İstanbul for teaching Turkish as a foreign/second language were examined and compared in terms of the compatibility with the competences specified in the CEFR. At this point, the distinction of 'writing/speaking as a production skill' and 'writing/speaking as an interaction skill' defined in the CEFR was used in the detailed analysis of the activities. As a result of the content analysis, it was found that there were differences and similarities in both course books in terms of the implementation of CEFR and the representation of A2 level descriptors. Although both course books claim to have been developed with reference to the CEFR, findings showed that they do not reach the learning outcomes in terms of speaking and writing skills related to 'interaction' and 'production' specified in the CEFR at the same rate. Basically, the study concluded that 'interaction' skills in Headway and 'production' skills in Yeni Istanbul are prioritized. The results also emphasize that these two course books need to be revised and reorganized to reflect the CEFR at A2 level.
\end{abstract}

Keywords: Foreign/second language teaching course books, CEFR, speaking skill, writing skill.

ÖZ: Bu çalışma, yabancı/ikinci dil öğretiminde anlatma becerileri (konuşma-yazma) açısından, Avrupa Dilleri Ortak Çerçeve Programında (CEFR) yer alan yeterliliklerin dil öğretimi ders kitaplarında ne ölçüde yerine getirildiğini araştırmayı amaçlamaktadır. Bu amaçla, çalışmada yabanc1/ikinci dil olarak İngilizce öğretim kitabı Headway ve yabancı/ikinci dil olarak Türkçe öğretim kitabı Yeni İstanbul; konuşma ve yazma etkinliklerinin CEFR yeterlilikleri ile uygunluğu açısından incelenmiş ve karşılaştırılmıştır. Bu noktada CEFR'de yer alan 'üretim becerisi olarak yazma/konuşma' ve 'etkileşim becerisi olarak yazma/konuşma' ayrımı etkinliklerin detaylı analizinde kullanılmıştır. İçerik analizinin sonucunda CEFR'nin uygulanması ve A2 düzeyi tanımlayıcıların temsili açısından her iki ders kitabında farklılıklar ve benzerlikler olduğu görülmüştür. $\mathrm{Bu}$ iki ders kitabının da CEFR referans alınarak geliştirildiği belirtilmesine rağmen, CEFR'de yer alan konuşma ve yazma becerileriyle ilgili öğrenme çıktılarına 'etkileşim' ve 'üretim' becerileri açısından aynı oranda ulaşamadıkları tespit edilmiştir. Temel olarak Headway'de 'etkileşim' becerilerinin; Yeni İstanbul'da ise 'üretim' becerilerin öncelendiği görülmüştür. Bulgular, iki ders kitabının da CEFR'yi A2 düzeyinde yansıtmak için revize edilmesi ve yeniden düzenlenmesi gerektiğini vurgulamaktadir.

Anahtar kelimeler: Yabanc1/ikinci dil öğretimi ders kitapları, CEFR, konuşma becerisi, yazma becerisi.

\footnotetext{
* Corresponding Author: Research Assistant, Kastamonu University, Department of Turkish Education, Kastamonu, Turkey, ifdemirel@kastamonu.edu.tr, https://orcid.org/0000-0002-9647-2672

** English Instructor, Kastamonu University, School of Foreign Languages, Kastamonu, Turkey, ozlemfakazli@kastamonu.edu.tr, https://orcid.org/0000-0003-4509-607X
}

\section{Citation Information}

Demirel, İ. F., \& Fakazlı, Ö. (2021). A CEFR-based comparison of English and Turkish Language teaching course books in terms of speaking and writing skills. Kuramsal Eğitimbilim Dergisi [Journal of Theoretical Educational Science], 14(2), 167-185. 
In a new, changing, globalized world, communicative language abilities have gained more importance. Being a linguistically competent, open-minded and responsible world citizen will add more values to the individual in culturally diverse societies. Since language is surely the most useful means of communication, language learning has become even more and more important in today's interconnected world. A learner is considered successful as long as they can master four basic language skills; namely reading, listening, speaking, writing. These skills are mainly divided into two main groups in the literature. The first one is reading and listening, which are described as receptive skills, and the second one is writing and speaking, which are described as productive skills.

In his second language acquisition theory, Krashen (2009) also expresses speaking and writing skills as the outputs of language and argues that the development of these two skills takes a long time. With these two skills in the target language, the learner engages in production activities and interaction. The area specified as production and interaction activities in CEFR (2020) includes speaking and writing skills. With their oral and written production skills, the language learner can make short statements, create anecdotes, prepare formal or informal presentations, engage in academic production activities, and express oneself professionally. The learner is expected to be fluent and clear while doing all these. All these production skills are not acquired easily in the natural operating process of language. In order for a language learner to be able to do these production and interaction activities in the target language, a period of time and mastery in that language are required.

Regarding teaching and learning a foreign/second language, it would be suitable to examine the CEFR in detail as a reference because the CEFR (2020, p. 11), which "is one of the best-known and most used Council of Europe policy instruments", draws a specific framework and offers suggestions for language learners, language teachers and those who prepare foreign/second language teaching course books. More specifically, CEFR (2020, p. 28) aims to:

- "promote and facilitate co-operation among educational institutions in different countries;

- provide a sound basis for the mutual recognition of language qualifications;

- assist learners, teachers, course designers, examining bodies and educational administrators to situate and co-ordinate their efforts".

Thus, the CEFR is the basis of the foreign/second language teaching process while developing education programs that include these four main skills in the language teaching process; developing the instructions of these programs, preparing textbooks and exams. The CEFR comprehensively determines what learners have to learn and do to meet their communicative needs in the target language. The CEFR also clarifies which knowledge and skills the learner needs to develop in order to be successful in the communicative and declarative dimensions of the language and the skills that are expected to be acquired at the end of the learning process. The CEFR aims to realize all these by also including the cultural dimension of the language in the process. Additionally, the CEFR also defines the language proficiency levels required to measure the learner's achievements at every stage of the learning process. 
Communicative language activities and strategies in CEFR, which was updated in 2020, are detailed as 'Reception', 'Production', 'Interaction' and 'Mediation'. With respect to speaking and writing skills, CEFR has two basic categories; these are 'production' and 'interaction' skills in CEFR. They are also divided into "oral production/written production" and "oral interaction/written interaction" separately. Production activities are defined under two categories, namely oral production and written production. Oral production includes six subcategories as learning outcomes; these are 'overall oral production', 'sustained monologue: describing experience', 'sustained monologue: giving information', 'sustained monologue: putting a case', 'public announcements', 'addressing audiences'. On the other hand, written production involves three subcategories as learning outcomes; these are 'overall written production', 'creative writing', 'reports and essays' (CEFR, 2020, p. 61). (see 2020 CEFR Companion Volume for details on the competences under the categories)

As for interaction activities, they are defined under three categories, namely oral interaction, written interaction, and online interaction. Under the category of oral interaction, there are ten subcategories; namely, 'overall interaction', 'understanding an interlocutor', 'conversation', 'informal discussion (with friends)', 'formal discussion (meetings)', 'goal-oriented co-operation', 'obtaining goods and services', 'information exchange', 'interviewing and being interviewed', 'using telecommunications'. There are 'overall written interaction', 'correspondence', and 'notes, messages and forms' under the category of written interaction. The third category, which is online interaction, has 'online conversation and discussion', 'goal-oriented online transactions and collaboration' as subcategories. (CEFR, 2020, p. 71). (see 2020 CEFR Companion Volume for details on the competences under the categories)

There are various reasons why an individual needs to learn a foreign/second language. In the study conducted by Tok and Yigin (2013) in the field of teaching Turkish as a foreign language, the reasons for international students to learn Turkish were investigated. A total of 57 foreign students learning Turkish from 34 different countries participated in the study and the reasons of learners to learn Turkish were academic reasons (26), economic reasons (22), touristic reasons (16), kinship tiesTurkic Republics (8), historical ties (6), political reasons (5), marriage (2), religious ties (2) (Tok \& Yigin, 2013, p. 139). As can be seen, the main reasons for students to learn Turkish as a foreign language were academic reasons. In this regard, it is of importance to mention the data released by UNESCO in 2018. This data showed that Turkey is the 10th country in the world, which has the largest number of international students with 125.138 international students in higher education. This number was 48.183 , according to the data in 2014. Thus, it is expected that the increase in the number of international students in only four years may affect the policies in teaching Turkish as a foreign language. Karakaya-Özyer and Y1ld1z (2020) conducted a study with 281 participants who learned/were learning Turkish as a foreign language in order to continue their higher education. As a result of the study, it was found that the reasons for international students' preferences in Turkey differed according to the regions the students come from. This suggests that university administrations should take internationalization into account, and the education system should be enriched with necessary strategies and changes accordingly. 
By taking internalization into consideration, one of the critical things that can be done is revising and reorganizing the language course books and materials. While doing so, the most important basis should be the CEFR. If the books and materials are compatible with the CEFR criteria, it is believed to make the teaching-learning process more efficient for both teachers and learners.

In Turkey, some regulations and reforms in teaching English as a foreign language have been made for a long time (Dincer \& Koç, 2020). However, systematic and planned academic studies in the field of teaching Turkish as a foreign language have gained momentum since the 1990s. As stated by Tüm (2017, p. 494), the studies conducted during these years were mostly based on general problems and the studies were insufficient because the course materials were limited in number and form. Although the lack of an undergraduate education program in the field is still considered to be a deficiency, important studies have been put forward at the postgraduate level. For example, it can be mentioned that there is a significant improvement in terms of Teaching Sets of Turkish as a Foreign Language compared to the 1990s. There are currently Turkish teaching sets for use in the field under the leadership of institutions such as Ankara University, Gazi University, Dokuz Eylül University, Hacettepe University, and Yunus Emre Institute. These teaching sets seem to contribute to the field of teaching Turkish as a foreign language both qualitatively and quantitatively.

It can also be said that textbooks and extracurricular materials used in foreign/second language teaching are accepted as usable and effective to the extent that they comply with the CEFR. In his study, Tomlinson (2012) states that textbooks in foreign/second language teaching are often preferred because of their ease of transportation, saving time, being affordable, and gathering many needs of the teacher in a single source. This situation is based on a survey conducted by British Council in 2008. According to the survey that investigates textbooks use of instructors, $65 \%$ of the foreign/second language teachers answered the question about the use of textbooks 'always' and 'often'. Only 6\% of the participants said 'never' (Tomlinson, 2012, p. 158). Thus, textbooks turned out to be one of the most basic resources that language teachers and students need. In this respect, teaching English, which is spoken in 101 countries (Uzun, 2012) and accepted as 'lingua franca', and which is the official language of more than 50 countries, is a significant resource for teaching Turkish and other languages as a foreign/second language in terms of its methods, techniques, strategies, materials and also language teacher education.

In the literature, there are some studies conducted to investigate the course books with reference to the CEFR. One of these studies was carried out by Tüm and Parmaksız-Emre (2017). In their study, they evaluated Yeni Hitit 1 Turkish teaching course book prepared by Ankara TÖMER and Success English language teaching course book. Specifically, speaking parts of both course books were examined according to the CEFR self-assessment criteria. The study found that while both books prioritized interactional skills, they did not give sufficient emphasis on productive skills. Given this outcome, Tüm and Parmaksız-Emre (2017) stated that teachers are required to take more responsibility in the teaching process. For example, teachers can select and create additional resources for their students. Tüm and Parmaksız-Emre also (2017) argued that these books include formal use of the language rather than different language use for different contexts in terms of linguistic patterns. They further 
emphasized that this does not help learners use real communicative language structures. In this respect, this study recommends more CEFR-based revisions and strengthening of course books. Another comparative study by Tuzcu-Eken and Dilidüzgün (2014) investigated Yeni Hitit 1 and New Headway in terms of listening comprehension exercises by taking the CEFR as a basis. The analysis showed that both course books need to be revised and developed in order to teach listening skills more effectively. Ünlü (2015) also carried out a comparative study and examined Hitit (older version of Yeni Hitit) and Yeni Hitit1 Turkish teaching course book in terms of their grammar and grammar exercises. The study concluded that there are some elements which need reviewing in terms of grammar. Fişne, Güngör, Guerra, and Gonçalves (2018, p. 129) in their comprehensive study examined "the 3rd and 4th grade course books and the Turkish and Portuguese English language curricula through content analysis and crosscultural comparison". The course books were analyzed in terms of language skills with reference to the CEFR, A1 level descriptors and intercultural characteristics of the books. Results indicated that there are similarities and differences in Turkey and Portugal in terms of compatibility with the CEFR.

As it is seen, there are several studies which investigates course books in terms of various aspects based on the CEFR. However, there is still a need to carry out more related studies, which might significantly contribute to the research area. The findings of new studies might also help educators and material and course book designers. Moreover, further studies could help to find out whether other different course books reflect the criteria suggested in the CEFR.

Taking all these into consideration, the current study aims at evaluating two different course books. Headway used for teaching English as a foreign/second language and Yeni İstanbul used for teaching Turkish as a foreign/second language were examined in terms of production and interaction skills as suggested in the descriptor scale of CEFR. Speaking and writing language skills are represented under the category production and interaction in the CEFR. However, it is important to note that this study only focused on speaking and writing activities of the course books, the category of 'online interaction' was not included in the study. Therefore, in the current study, all speaking and writing activities were evaluated based on the criteria defined in the related categories of CEFR Illustrative Descriptor Scales. Another important issue is that the study is based on the final edition of the "CEFR Companion Volume", which was updated in 2020.

\section{Aim of the Study}

The main objective of the study is to compare Headway and Yeni İstanbul in terms of writing and speaking activities based on The Common European Framework of Reference for Languages (CEFR). With this purpose in mind, the following research questions were addressed in the study:

1. What is the percentage of writing and speaking activities in Headway (A2 level) and Yeni İstanbul (A2 level)?

2. Are the writing and speaking activities in Headway (A2 level) designed according to the criteria determined in CEFR?

3. Are the writing and speaking activities in Yeni İstanbul (A2 level) designed according to the criteria determined in CEFR? 
4. To what extent are writing and speaking activities included in Headway (A2 level) and Yeni İstanbul (A2 level) suited to CEFR when they are compared?

\section{Method}

\section{Design of the Study}

The current study was designed as qualitative research. Qualitative research is a type of investigation in which such data collection tools as document analysis, interviews, observations are employed, individuals' experiences, interpretations and perceptions are explored in detail, and findings are presented in a holistic approach (Creswell, 2018; Merriam, 2013; Y1ldırım \& Şimşek, 2013). Qualitative research aims to examine, understand, interpret, explain a social phenomenon in its own context.

\section{Data Collection Instrument}

In order to seek answers to the research questions, document analysis was used as a data collection tool. Document analysis is "a method of collecting data from existing records and documents" (Karasar, 2020, p. 229). According to Ekiz (2009), document analysis is to collect official and private records, analyze and evaluate these records systematically. Through this method, related documents are analyzed progressively and elaborately (Yıldırım \& Şimşek, 2013).

In accordance with the objectives of the study, two different course books were investigated. One of them is Headway (A2 level), the other is Yeni İstanbul (A2 level). More specifically, the writing and speaking activities of these two books were examined in detail, and it was aimed to identify whether these activities are compatible with the CEFR descriptor for A2 level. The reason why these books were chosen for the purpose of the study is that they are widely used for teaching the target languages, English and Turkish, in Turkey.

Headway course books have been published by Oxford University Press in order to be used for teaching English across the world. Headway series are currently composed of six different language proficiency levels from Beginner to Advanced level. This book has also been widely preferred as the main course book in English Preparatory Schools of the universities in Turkey. Headway examined in the current study is the fifth edition, which is the last edition of this series.

The number of the units may change from one language level course book to another. Headway (A2 level) includes 12 units, and every unit consists of grammar, vocabulary, reading, listening, writing sections besides everyday English section for speaking. More specifically, Headway fifth edition provides comprehensive and functional vocabulary and grammar presentation and practice. Moreover, each unit aims at improving integrated skills; namely reading, writing, listening, speaking, which is of great importance in learning a new language. Thus, it is understood that the book has been prepared based on skills syllabus. Headway also claims to aid millions of students to realize their potential throughout the journey of learning a language. Another significant issue is that Headway puts forward that it has been produced considering the objectives of CEFR.

Yeni İstanbul, which is a series of course books, has been planned in a communicative and student-oriented way and designed based on the language 
proficiency levels determined by CEFR. It includes six levels in congruent with the learning outcomes of CEFR. Yeni İstanbul has been produced by İstanbul University DILMER, and it aims to teach Turkish, which is the official language of Turkey, in modern and up-to-date methods.

Yeni İstanbul has been prepared for each language level as claimed in the foreword of the book, and each book is composed of six units arranged according to the subject matters following the objectives of CEFR. Each unit is separated into three parts. At the beginning of every unit, skills to be taught, grammar and vocabulary groups are provided. Moreover, the format of each unit is systematically designed the same. The units start with warm-up activities and continue with the sections of "reading, what about you?, grammar, listening, speaking, writing". At the end of the units, the sections "from culture to culture, classroom language, let's enjoy and learn, what have we learned?, self-evaluation and vocabulary list" are available.

It is of great significance to specify that almost all of the course books including Headway and Yeni İstanbul claim to have been developed based on The Common European Framework of Reference for Languages (CEFR). "The Common European Framework provides a common basis for the elaboration of language syllabuses, curriculum guidelines, examinations, textbooks, etc. across Europe" (Council of Europe, 2001: 1).

\section{Data Analysis}

Writing and speaking activities developed for A2 language proficiency level in Headway and Yeni İstanbul were investigated based on production and interaction stated in the CEFR descriptor for A2 level. For coding and categorizing the qualitative data, content analysis was conducted. This is implemented based on "the process of summarizing and reporting written data - the main contents of data and their messages" (Cohen, Manion, \& Morrison, 2007, p. 475).

As for the in-depth data analysis procedure, firstly, how many units each course book includes and how many writing and speaking activities each unit has were determined. In this way, the percentage of the activities for each unit in both course books was identified. Following this, writing and speaking activities were evaluated according to the production and interaction outcomes for A2 language proficiency level suggested in CEFR. At this point, it is noteworthy to say that writing and speaking tasks correspond to production and interaction activities in CEFR. That is why, by comparing and contrasting, the activities for both skills were categorized as production and interaction activities as suggested in the CEFR descriptor. More specifically, after categorizing the tasks as production or interaction, each activity was also positioned under the related sub-heading in CEFR. Eventually, completing the analysis of the speaking and writing activities of each course book in terms of oral/written production and oral/written interaction in CEFR, the collected data were presented as frequencies and percentages in order to indicate to what extent the course books reflect the learning outcomes in the CEFR descriptor for A2 level.

It is of importance to state that the collected data were analyzed by four different raters. The two researchers of this study and two other independent raters, who had experience in document analysis and who were course book users as language teachers, analyzed the data in order to abstain from researchers' subjectivity and to ensure 
interrater- reliability. Inter-rater reliability was identified by using "[agreement / (agreement + disagreement)] X 100” formula (Miles \& Huberman, 1994) and found .84, which shows a high level of reliability.

\section{Limitations}

The study has the following limitations:

1. Only Headway and Yeni İstanbul course books for teaching languages are employed in the current study.

2. Among all six different language proficiency levels defined as Common Reference Levels in CEFR, only A2 level course books are included in the study.

3. Only speaking and writing activities were examined in the study.

\section{Results}

In this section, based on the analysis of two different course books, the findings were presented.

Table 1

The Number of Speaking and Writing Activities in Yeni Istanbul

\begin{tabular}{lccc}
\hline Unit & Writing & Speaking Activity & The number of activities in each unit \\
\hline Unit 1 & 5 & 7 & 12 \\
Unit 2 & 3 & 14 & 17 \\
Unit 3 & 3 & 8 & 11 \\
Unit 4 & 3 & 9 & 12 \\
Unit 5 & 3 & 10 & 13 \\
Unit 6 & 3 & 56 & 11 \\
Total & 20 & $9(9.33)$ & 76 \\
Average & $3(3.33)$ & & $13(12.66)$ \\
\hline
\end{tabular}

In the beginning, while determining the number of activities, end-of-unit evaluation sections of Yeni İstanbul course books were not included in the study. Table 1 indicates that the activities did not show a homogeneous distribution in terms of productive language skills in A2 level Istanbul course book. The average speaking activity per unit is around three times higher than the average writing activity. Given the total number of activities based on writing and speaking skills used in the book, it was seen that the number of speaking activities is around three times higher than the writing activities. This outcome suggests that speaking skill takes precedence over writing, which is another productive language skill. 
Table 2

Evaluation of the Activities in terms of Oral Production/Interaction and Written Production/Interaction in CEFR for Yeni İstanbul

\begin{tabular}{lc}
\hline Skills & Total Use \\
\hline Oral Production Skills & 42 \\
Written Production Skills & 16 \\
Oral Interaction Skills & 19 \\
Written Interaction Skills & 5 \\
Total & 82 \\
\hline
\end{tabular}

On the basis of the examination, the total number of production-oriented (oral and written production) activities was determined as 58, and the number of interactionoriented (oral and written interaction) activities was determined as 24. Especially written interaction skills were activated five times only in the first and third units. In parallel with the results in Table 1, an inhomogeneous distribution in terms of activating production and interaction skills in activities was observed in Table 2. Results also indicate that oral/written production and oral/written interaction skills were activated 82 times in the 76 writing/speaking activities in the book. This finding indicates that more than one skill was activated in some of the activities.

Table 3

The Frequency of Oral and Written Production Skills According to CEFR for Yeni Istanbul

\begin{tabular}{|c|c|c|c|c|c|}
\hline 1-) Oral Production & $\begin{array}{l}\text { Frequency } \\
\text { of use }\end{array}$ & Units & 2-) Written Production & $\begin{array}{l}\text { Frequency } \\
\text { of use }\end{array}$ & Units \\
\hline $\begin{array}{l}\text { 1-a) Overall Oral } \\
\text { Production }\end{array}$ & 14 & $1-2-3-5-6$ & $\begin{array}{l}\text { 2-a) Overall Written } \\
\text { Production }\end{array}$ & 5 & $1-3-5$ \\
\hline $\begin{array}{l}\text { 1-b) Sustained } \\
\text { monologue:Describing } \\
\text { experience }\end{array}$ & 32 & $1-2-3-4-5-6$ & 2-b) Creative writing & 6 & $2-3-4-5$ \\
\hline $\begin{array}{l}\text { 1-c) Sustained } \\
\text { monologue:Giving } \\
\text { information }\end{array}$ & 1 & 1 & 2-c) Reports and Essays & 11 & $\begin{array}{l}1-2-3- \\
4-5-6\end{array}$ \\
\hline $\begin{array}{l}\text { 1-d) Sustained } \\
\text { monologue:Putting a } \\
\text { case }\end{array}$ & 3 & 2 & & & \\
\hline $\begin{array}{l}\text { 1-e) Public } \\
\text { Announcements }\end{array}$ & - & - & & & \\
\hline $\begin{array}{l}\text { 1-f) Addressing } \\
\text { audiences }\end{array}$ & 3 & $3-5$ & & & \\
\hline Total & 53 & & & 22 & \\
\hline
\end{tabular}


Since the study focused on 'speaking' and 'writing', which are productive language skills, 'Production' and 'Interaction' sections were examined in CEFR. In Table 3, production skills were examined in terms of writing and speaking activities in Yeni Istanbul course book. Table 3 demonstrates that oral production skills come to the fore significantly in parallel with overall activities identified in Table 1. 53 oral production skills were aimed to activate in 56 speaking activities in the book. However, these 53 oral production skills did not show a homogeneous distribution within themselves. Among six oral production skills specified in the CEFR, only 'Overall Oral Production Skills' and 'Sustainable Monologue: Explanation' were targeted to improve 46 times in total. The 'Public Announcements' skill was never included in the book as a skill. This result means that the activities used in the book do not contribute to the development of all skills included in the CEFR.

Written production skills showed a more homogeneous distribution than oral production skills. In 20 writing skill activities in the book, three skills determined in the CEFR were aimed to improve 22 times in total. All three skills were determined to be close to or above average usage.

Table 4

The Frequency of Oral and Written Interaction Skills according to CEFR for Yeni Istanbul

\begin{tabular}{|c|c|c|c|c|c|}
\hline 3-) Oral Interaction & $\begin{array}{l}\text { Frequency } \\
\text { of use }\end{array}$ & Units & 4-)Written Interaction & $\begin{array}{l}\text { Frequency } \\
\text { of use }\end{array}$ & Units \\
\hline $\begin{array}{l}\text { 3-a) Overall Oral } \\
\text { Production }\end{array}$ & 13 & $1-2-3-4-5-6$ & $\begin{array}{l}\text { 4-a) Overall written } \\
\text { interaction }\end{array}$ & 1 & 3 \\
\hline $\begin{array}{l}\text { 3-b) Understanding an } \\
\text { interlocutor }\end{array}$ & 12 & $2-3-4-5-6$ & 4-b) Correspondence & - & - \\
\hline 3-c) Conversation & 12 & $2-3-4-5-6$ & $\begin{array}{l}\text { 4-c) Notes, Messages } \\
\text { and Forms }\end{array}$ & 4 & $1-3$ \\
\hline $\begin{array}{l}\text { 3-d) Informal } \\
\text { Discussion (Friends) }\end{array}$ & 2 & $2-3$ & & & \\
\hline $\begin{array}{l}\text { 3-e) Formal Discussion } \\
\text { (Meetings) }\end{array}$ & - & - & & & \\
\hline $\begin{array}{l}\text { 3-f) Goal-Oriented } \\
\text { Cooperation }\end{array}$ & 5 & $1-3-6$ & & & \\
\hline $\begin{array}{l}\text { 3-g) Obtaining goods } \\
\text { and services }\end{array}$ & 3 & $1-6$ & & & \\
\hline $\begin{array}{l}\text { 3-h) Information } \\
\text { Exchange }\end{array}$ & 11 & $1-2-3-4-5-6$ & & & \\
\hline $\begin{array}{l}3 \text {-i) Interviewing and } \\
\text { being interviewed }\end{array}$ & - & - & & & \\
\hline $\begin{array}{l}\text { 3-j) Using } \\
\text { telecommunications }\end{array}$ & - & - & & & \\
\hline Total & 58 & & & 5 & \\
\hline
\end{tabular}


In Table 4, the speaking and writing activities in Yeni Istanbul course book were also evaluated in terms of interaction. CEFR includes ten subcategories for 'Oral Interaction' and three sub-categories for 'Written Interaction'. It is seen that 'Oral Interaction' skills were aimed to foster 58 times through 56 speaking activities in the book. However, it is observed that the distribution is not homogeneous again. Three oral interaction skills $(3-\mathrm{e}, 3-\mathrm{i}, 3 \mathrm{j})$ did not find a place among the speaking activities in the book, and three oral interaction skills (3-d, 3-f, 3-g) were used very limitedly. Therefore, it can be said that all of the 'Oral Interaction Skills' in the CEFR could not be completely achieved through the speaking activities in the book.

In parallel with the distribution of activities throughout the book, 'Written Interaction' skills are found to be inadequate in quantity, especially compared to 'Oral Interaction' skills. While seven skills were intended to develop 58 times regarding oral interaction, two skills were focused five times in total in terms of written interaction.

While speaking skill in the book shows consistency within itself in both oral production and oral interaction dimensions (oral production 53, oral interaction 58), this cannot be said for writing skill. In terms of enhancing writing skills, "Written Production Skills" in the CEFR are included 22 times in the book while "Written Interaction Skills" are included only five times.

Table 5

The Number of Speaking and Writing Activities in Headway

\begin{tabular}{lccc}
\hline Unit & Writing activity & Speaking activity & The number of activities in each unit \\
\hline Unit 1 & 2 & 6 & 8 \\
Unit 2 & 1 & 8 & 9 \\
Unit 3 & 1 & 9 & 10 \\
Unit 4 & 4 & 6 & 10 \\
Unit 5 & 1 & 6 & 7 \\
Unit 6 & 1 & 9 & 10 \\
Unit 7 & 3 & 7 & 10 \\
Unit 8 & 1 & 7 & 8 \\
Unit 9 & 1 & 8 & 9 \\
Unit 10 & 1 & 7 & 8 \\
Unit 11 & 2 & 8 & 10 \\
Unit 12 & 1 & 6 & 7 \\
Total & 19 & 87 & 8.83 \\
Average & 1.58 & 7.25 & \\
\hline
\end{tabular}

When all the units in Headway A2 level were analyzed, it was seen in Table 5 that the total number of activities in each unit is close to the other units. However, as Table 5 shows, there is no homogeneous distribution between writing and speaking activities. The number of speaking activities is around four times greater than writing activities. It is obviously understood that Headway prioritized speaking activities over 
writing activities. Thus, the book primarily appears to aim at improving speaking skills and accordingly included more activities for this purpose and preferred to keep the number of writing activities at a minimum.

Table 6

Evaluation of the Activities in terms of Oral Production/Interaction and Written Production/Interaction in CEFR for Headway

\begin{tabular}{lc}
\hline Skills & Total use \\
\hline Oral Production Skills & 26 \\
Written Production Skills & 15 \\
Oral Interaction Skills & 66 \\
Written Interaction Skills & 4 \\
Total & 111 \\
\hline
\end{tabular}

In Table 6, the productive skills-based activities in Headway were evaluated in terms of the production and interaction outcomes that are defined under the title of Communicative language activities and strategies in The CEFR Illustrative Descriptor Scales. On the basis of the analysis, whereas the total number of production-oriented (oral and written production) activities was 41, the number of interaction-oriented activities (oral and written interaction) was 70. This suggests that Headway focuses more on providing and enhancing interaction among students during classroom activities than only making them productive without interaction. When comparing the total number of the activities in Table 5 to the number of the activities prompting oral and written production and oral interaction and written interaction, it was found that the numbers are not the same. The book aims to foster 111 skills through a total of 106 writing and speaking activities. This is because some activities aim to stimulate more than one skill. Hence, it is significant to note that one activity might serve different production and oral skills simultaneously. Moreover, as shown in Table 6, there is no homogeneous distribution among oral production/written production and oral interaction/written interaction skills.

Since the study focused on speaking and writing skills, which are productive language skills, Headway course book also was examined in terms of 'Production' and 'Interaction' sections in CEFR as in Yeni İstanbul. Table 7 demonstrates the frequency of oral and written production skills that Headway aims to develop through speaking and writing activities. The results revealed that the frequency of oral production skills addressed in all the activities of Headway was three times higher than the frequency of written production skills. 
Table 7

The Frequency of Oral and Written Production Skills According to CEFR for Headway

\begin{tabular}{|c|c|c|c|c|c|}
\hline 1-) Oral Production & $\begin{array}{l}\text { Frequency } \\
\text { of use }\end{array}$ & Units & $\begin{array}{l}\text { 2-) Written } \\
\text { Production }\end{array}$ & $\begin{array}{l}\text { Frequency } \\
\text { of use }\end{array}$ & Units \\
\hline $\begin{array}{l}\text { 1-a) Overall Oral } \\
\text { Production }\end{array}$ & 19 & $\begin{array}{l}1-2-4-6-9- \\
10-11-12\end{array}$ & $\begin{array}{c}\text { 2-a) Overall } \\
\text { Written Production }\end{array}$ & 4 & $\begin{array}{c}1-2-4- \\
12\end{array}$ \\
\hline $\begin{array}{l}\text { 1-b) Sustained monologue: } \\
\text { Describing experience }\end{array}$ & 22 & $\begin{array}{c}1-2-3-4-6- \\
7-9-10-11- \\
12\end{array}$ & $\begin{array}{l}\text { 2-b) Creative } \\
\text { writing }\end{array}$ & 8 & $\begin{array}{c}1-4-6- \\
7-11\end{array}$ \\
\hline $\begin{array}{l}\text { 1-c) Sustained monologue: } \\
\text { Giving information }\end{array}$ & 1 & 9 & $\begin{array}{l}\text { 2-c) Reports and } \\
\text { Essays }\end{array}$ & 3 & $7-9-10$ \\
\hline $\begin{array}{l}\text { 1-d) Sustained monologue: } \\
\text { Putting a case }\end{array}$ & 2 & $5-11$ & & & \\
\hline $\begin{array}{l}\text { 1-e) Public } \\
\text { Announcements }\end{array}$ & - & - & & & \\
\hline 1-f) Addressing audiences & 1 & 11 & & & \\
\hline Total & 45 & & & 15 & \\
\hline
\end{tabular}

When the Table 7 was examined in detail in parallel with Table 5, a total of 87 speaking activities were prepared to develop 45 oral production skills. However, there is no homogeneous distribution among all different six subcategories of oral production skills defined in CEFR. The competence of 'Sustained monologue: Describing Experience' ranked the first in terms of the frequency $(n=22)$, followed by 'Overall Oral Production' $(n=19)$. The competence of 'Public Announcements' is never intended to promote in the course book. On the other hand, considering the findings in Table 5 again, 19 writing activities were added to the course book in order to improve 15 written production skills. In terms of the frequencies of three subcategories of written production, it is observed that 'Creative Writing' was aimed to build the most $(n=8)$, succeeded by 'Overall Written Production' $(n=4)$ and 'Reports and Essays' $(n=3)$.

Table 8 indicates the frequency of oral and written interaction skills that Headway aims to develop through speaking and writing activities. When the Table 8 was gone through in detail together with Table 5, 87 speaking activities were intended to develop a total of 161 oral interaction skills. Among all ten different oral interaction learning outcomes defined in CEFR, 'Informal Discussion with Friends' was aimed to teach the most $(n=32)$, followed by 'Overall Oral Production' $(n=30)$ and 'Conversation' $(n=30)$. Another striking finding is that Headway does not aim to promote 'Formal Discussion Meetings' and 'Using Communications' (3-e, 3j). 
Table 8

The Frequency of Oral and Written Interaction Skills according to CEFR for Headway

\begin{tabular}{|c|c|c|c|c|c|}
\hline 3-) Oral Interaction & $\begin{array}{l}\text { Frequency } \\
\text { of use }\end{array}$ & Units & 4-)Written Interaction & $\begin{array}{l}\text { Frequency } \\
\text { of use }\end{array}$ & Units \\
\hline $\begin{array}{l}\text { 3-a) Overall Oral } \\
\text { Production }\end{array}$ & 30 & $\begin{array}{c}1-2-3-4-5-6-7- \\
8-11-12\end{array}$ & $\begin{array}{l}\text { 4-a) Overall written } \\
\text { interaction }\end{array}$ & - & - \\
\hline $\begin{array}{l}\text { 3-b) Understanding an } \\
\text { interlocutor }\end{array}$ & 25 & $\begin{array}{l}1-2-3-4-7-8- \\
11-12\end{array}$ & 4-b) Correspondence & 3 & $5-8$ \\
\hline 3-c) Conversation & 30 & $\begin{array}{l}1-2-3-4-5-6- \\
10-11-12\end{array}$ & $\begin{array}{l}\text { 4-c) Notes, Messages } \\
\text { and Forms }\end{array}$ & 1 & 3 \\
\hline $\begin{array}{l}\text { 3-d) Informal } \\
\text { Discussion (Friends) }\end{array}$ & 32 & $\begin{array}{c}2-3-4-5-6-7-8- \\
9-10-11-12\end{array}$ & & & \\
\hline $\begin{array}{l}\text { 3-e) Formal Discussion } \\
\text { (Meetings) }\end{array}$ & - & - & & & \\
\hline $\begin{array}{l}3-\mathrm{f}) \text { Goal-Oriented } \\
\text { Cooperation }\end{array}$ & 14 & $\begin{array}{c}3-4-5-7-8-9- \\
10-11\end{array}$ & & & \\
\hline $\begin{array}{l}\text { 3-g) Obtaining goods } \\
\text { and services }\end{array}$ & 5 & $4-6-8-9$ & & & \\
\hline $\begin{array}{l}\text { 3-h) Information } \\
\text { Exchange }\end{array}$ & 24 & $\begin{array}{c}1-2-3-4-5-6-7- \\
8-9-11-12\end{array}$ & & & \\
\hline $\begin{array}{l}3 \text {-i) Interviewing and } \\
\text { being interviewed }\end{array}$ & 1 & 11 & & & \\
\hline $\begin{array}{l}\text { 3-j) Using } \\
\text { telecommunications }\end{array}$ & - & - & & & \\
\hline Total & 161 & & & 4 & \\
\hline
\end{tabular}

On the other hand, in parallel with the findings in Table 5 again, 19 writing activities only served to improve written production skills four times. In terms of the frequencies of three subcategories of written production, it is obvious that the frequency of 'Correspondence' in the course book was the highest $(n=3)$ whereas 'Overall Written Interaction' was never included as a skill (4-a). Therefore, it can be suggested that all of the 'Oral Interaction' and 'Written Interaction' outcomes defined in the CEFR could not be achieved through the speaking and writing activities in Headway.

Based on all these analyses, it can be put forward that Headway put much emphasis on oral production and interaction skills compared to written production and written interaction skills. There already exists a significant difference in quantity between speaking and writing activities. Moreover, in accordance with a high number of speaking activities, speaking skills represented under oral production and oral interaction in CEFR are aimed to improve the most. However, when considering the frequencies of oral production and interaction separately, it was found that oral interaction skills were given significant priority over oral production. Thus, it can be argued that Headway serves to promote interaction by primarily activating oral interaction skills instead of written interaction. 


\section{Discussion}

The current study aimed at investigating to what extent the competences defined in CEFR are reflected in language teaching course books in terms of speaking and writing skills. To this end, Headway and Yeni İstanbul were evaluated in detail based on CEFR. After presenting the findings for each book were provided separately in the previous section; here, in this section, two course books were evaluated together, and findings obtained were discussed thoroughly.

Table 9

Overall Comparison of Headway and Yeni Istanbul in terms of Reflection of the CEFR

\begin{tabular}{lcc}
\hline & Yeni İstanbul & Headway \\
\hline Activity per unit & 12.66 & 8.83 \\
Writing activity per unit & 3.33 & 1.58 \\
Speaking activity per unit & 9.33 & 7.25 \\
Frequency of Oral Production Skill & 42 & 26 \\
Frequency of Writing Production Skill & 16 & 14 \\
Frequency of Oral Interaction Skill & 19 & 66 \\
Frequency of Writing Interaction Skill & 5 & 5 \\
Production Skill Per Total Activity & .71 & .37 \\
Interaction Skill Per Total Activity & .31 & .66 \\
Production Skill Per Total Writing Activity & .8 & .73 \\
Interaction Skill Per Total Writing Activity & .25 & .26 \\
Production Skill Per Total Speaking Activity & .75 & .29 \\
Interaction Skill Per Total Speaking Event & .33 & .75 \\
\hline
\end{tabular}

For the analysis, frequencies and percentages were taken into account in the interpretation of the data because the total number of units was different. Whereas Headway has 12 units, Yeni İstanbul has 6 units. When the Table 9 is examined, Yeni Istanbul course book contains a bigger number of activities than Headway both in terms of total number and in terms of writing and speaking activities per unit separately. When these activities are considered quantitatively, it can be interpreted as a significant difference. However, when the activities were evaluated in terms of skills, the activities in Headway aim to improve more skills than Yeni İstanbul, which can be clearly understood when the number and the frequencies of activities are compared.

When the activities in the books were evaluated in terms of interaction and production skills, the main skill area planned to be activated and developed through the activities in Headway is interactive speaking and writing with 63.96\%. In Yeni Istanbul, this percentage is $29.26 \%$. This situation provides similar results in terms of skill per total activity. That is to say, whereas interaction skill-based activity per total speaking and writing activity in Yeni Istanbul is .31, this percentage is .66 in Headway, which is more than twice the number in Yeni Istanbul. This result highlights that Headway pays more attention to interaction during a language learning process. 
Similar results were found when the activities prepared for improving speaking skills were evaluated within themselves under two categories: interaction and production. The interactional skill per activity was .75 in Headway, while this rate was found to be .33 in Yeni Istanbul. Again, in this regard, it can be suggested that compared to Yeni İstanbul, Headway gives much more importance to enhancing interactional speaking skills rather than productive speaking skills. On the other hand, Yeni İstanbul turned out to disregard interaction by mainly focusing on production. Even though interaction is given more priority in Headway, "formal discussion with friends" and "using communications" in the CEFR A2 level descriptor are never included as learning outcomes. As for Yeni İstanbul, the frequency of interactional speaking skills is quite low, and also, the learning outcomes of "formal discussion with friends", "using communications" and "interviewing and being interviewed" are not realized.

In the light of the findings, it can also be put forward that the activities prepared for the development of writing skills are insufficient in quantity for both course books. In these two different materials, the number of activities prepared for writing skills is quite limited. Whereas the overall percentage of writing activities in Yeni İstanbul is $15.2 \%$, it is $17.92 \%$ in Headway. This outcome demonstrates that in both course books, the writing skill is primarily overshadowed by the speaking skill and is highly underestimated both in terms of interaction and production. This finding signifies that both do not appear to fully represent the CEFR descriptor A2 level in terms of writing skills.

To sum up, the current study arrived at the conclusion that the course books do not reach the learning outcomes at the same rate in terms of speaking and writing skills regarding 'interaction' and 'production' specified in the CEFR. Basically, the study concluded that 'interaction' skills in Headway and 'production' skills in Yeni Istanbul are prioritized.

With reference to the CEFR, writing skill is underrated in two course books both in terms of production and interaction. Instead, speaking skill is given more priority. However, in terms of two subcategories of speaking skills in CEFR, which are production and interaction, it was concluded that Headway mainly aims at improving interactional speaking skills. In contrast, Yeni İstanbul focuses on improving productive speaking skills, which is one of the main differences between the course books.

\section{Conclusion}

The study concluded that these course books are not proficient in achieving all the learning outcomes specified under oral/written production and oral/written interaction in CEFR. Even though they claim that they have been prepared with reference to the CEFR, it was found that they do not fully reflect all the learning outcomes suggested in the CEFR. Thus, the implementation of the CEFR and the representation of A2 level descriptor has not been completely realized in the course books.

Based on the findings, there seems a need for the course book writers to develop and redesign their books. In other words, these two course books need to be revised and reorganized to reflect the CEFR because there is still much room for improvement to be able to compatible with the CEFR A2 level descriptor. Especially, it would be better to 
design and add more writing activities to Headway and Yeni İstanbul in order to stimulate students' productive and interactive writing skills, which appear as insufficient in both of them. Another important thing is that Yeni İstanbul should put more emphasis on improving interactional skills in speaking activities, which turned out to be limited in the analysis. Additionally, both course books should also find a balance between oral/written production and oral/written interaction in terms of speaking and writing.

Considering some limitations of the course books, as Enever, Moon, and Raman (2009) suggest, teachers should be observed if they know about materials development and adaptation and curriculum evaluation. If teachers are educated in such areas at preservice teaching education and gain awareness of what the CEFR is and how it is important, they can overcome the drawbacks of the course books. They can adapt the course books, enrich the activities, create suitable content, new extra activities and materials in order to implement the CEFR. Thus, "pre-service teacher education programs also need to be redesigned by including the courses that enhance pre-service teachers implement the CEFR" (Fişne et al., 2018, p. 145). Similarly, Balcı (2017) and Bekteshi (2017) puts forward that in-service trainings can be provided to teachers about this issue. As Kennedy and Tomlinson (2013) highlight, evaluation of teaching materials and curriculum is fundamental, so teachers also need to develop their pedagogical skills in this area.

Given the findings and limitations of the study mentioned above, the current study puts forward some suggestions for further research. First of all, Headway and Yeni İstanbul could also be evaluated based on the CEFR in terms of reading and listening skills, which are described as receptive language skills. Additionally, another study could examine different language levels of these course books so that comparisons across different levels can be made. Further studies could also be carried out with other English and Turkish course book sets designed for teaching languages in order to find out whether they are compatible with the learning outcomes of CEFR.

\section{Statement of Responsibility}

İbrahim Fatih Demirel; resources, data collection, validation, analysis, writingoriginal draft, writing-review\&editing, visualization. Özlem Fakazlı; methodology, resources, data collection, validation, analysis, writing-original draft, writingreview\&editing, visualization, supervision. 


\section{References}

Balc1, B. (2017). A critical study on ELT course books regarding general competences presented in the common European Framework of references for languages (Unpublished doctoral dissertation). Çukurova University, Adana.

Bekteshi, E. (2017). English Language teaching and the common European Frame of reference: a comparison of ELT in Portugal and in the Republic of Kosovo. International Journal of ANGLISTICUM Literature, Linguistics Interdisciplinary Studies, 6(1), 40-53.

British Council. (2008). Teaching English: Course books. London.

Büyüköztürk, Ş., Kılıç-Çakmak, E., Akgün, Ö. E., Karadeniz, Ş., \& Demirel, F. (2019). Eğitimde bilimsel araştırma yöntemleri (27. basım). Ankara: Pegem Akademi.

Cohen, L., Manion, L., \& Morrison, K. (2007). Research methods in education (6th Edition). New York: Taylor \& Francis.

Council of Europe (2001). Common European Framework of Reference for Languages: Learning, teaching, assessment - Companion volume, Council of Europe Publishing, Strasbourg. Retrieved December 22, 2020 from https://rm.coe.int/1680459f97.

Council of Europe (2020). Common European Framework of Reference for Languages: Learning, teaching, assessment - Companion volume, Council of Europe Publishing, Strasbourg. Retrieved December 22, 2020 from https://rm.coe.int/common-european-framework-of-reference-for-languageslearning-teaching/16809ea0d4.

Creswell, J. (2018). Nitel araştırma yöntemleri (4.Baskı) (M. Bütün ve S.B. Demir Çev.Ed.). Ankara: Siyasal Kitabevi.

Dincer, A., \& Koç, H. K. (2020). The implementation of an intensive English language program in the fifth grade in Turkey: A qualitative evaluation. Journal of Theoretical Educational Science, 13(1), 25-43. http://doi.org/10.30831/akukeg.532955

Ekiz, D. (2009). Bilimsel araştırma yöntemleri (Geliştirilmiş 2. baskı). Ankara: Anı Yayınc1lik.

Enever, J., Moon, J., \& Raman, U. (2009). Young learner English language policy and implementation: International perspectives. Garnet Publishing.

Fişne, F. N., Güngör, M. N., Guerra, L., \& Gonçalves, O. (2018). A CEFR-based Comparison of ELT Curriculum and Course Books used in Turkish and Portuguese Primary Schools. Novitas-ROYAL (Research on Youth and Language), 12(2), 129151.

Karakaya-Özyer, K., \& Y1ldız, Z. (2020). Country-of-origin and International Students' Motivation in Turkey: A Correspondence Analysis. Journal of Theoretical Educational Science, 13(1), 44-64. https://www.doi.org/10.30831/akukeg.533005

Karasar, N. (2020). Bilimsel araştırma yöntemi (35. basım). Ankara: Nobel Akademik Yayınc1lik. 
Kennedy, C., \& Tomlinson, B. (2013). Implementing language policy and planning through materials development. In B. Tomlinson (Ed.), Applied linguistics and materials development, (pp. 255-267). India: Bloomsbury.

Krashen, S. (2009). Principles and practice in second language acquisition. Retrieved $\begin{array}{lll}\text { December } & 4, & 2020\end{array}$ http://www.sdkrashen.com/content/books/principles_and_practice.pdf.

Merriam, S. B. (2013). Nitel araştırma: Desen ve uygulama için bir rehber (S. Turan, Çev. Ed.). Ankara: Nobel Akademik Yayıncılık.

Miles, M. B., \& Huberman, A. M. (1994). Qualitative data analysis (2nd Ed.). United

Tok, M., \& Yııın, M. (2013). Yabancı uyruklu öğrencilerin Türkçe öğrenme nedenlerine ilişkin bir durum çalışması. Dil ve Edebiyat Eğitimi Dergisi, 8, 132147.

Tomlinson, B. (2012). Material development for language learning and teaching. Language Teaching, 45(2), 143-179.

Tuzcu-Eken, D., \& Dilidüzgün, Ş. (2014). The types and the functions of the listening activities in Turkish and English course books. Procedia - Social and Behavioral Science, 152, 989 -994.

Tüm, G. (2017). Yabancı dil olarak Türkçe öğretimi ders kitaplarına yöntemsel bakış: Tümevarım ve tümdengelim yöntemleri. Turkish Studies, 12, 491-500.

Tüm, G., \& Parmaksız-Emre, G. (2017). Comparison of speaking activities in Turkish and English language teaching coursebooks regarding self-assesment grid of CEFR. Journal of Language and Linguistic Studies, 13(2), 367-378.

Uzun, N. (2012). Türkçenin dünya dilleri arasındaki yeri üzerine. Türkoloji Dergisi, 19(2), 115-134.

Ünlü, A. (2015). A Comparison of the presentation of grammar and grammar exercises in Hitit 1 and Yeni Hitit 1. Hacettepe Üniversitesi Yabancı Dil Olarak Türkçe Araştırmaları Dergisi, 2(2), 137-150.

Yıldırım, A., \& Şimşek, H. (2013). Sosyal bilimlerde nitel araştırma yöntemleri. Ankara: Seçkin Yayıncılık. 